\title{
Thoracic aortic surgery: An overview of 40 years clinical practice
}

\author{
Jos A. Bekkers, MD, PhD, ${ }^{\text {a }}$ Roderick J. L. M. te Riele, ${ }^{a}$ Johanna J. M. Takkenberg, MD, PhD, ${ }^{\text {a }}$ \\ Goris Bol Raap, MD, PhD, ${ }^{\mathrm{a}}$ Jan Hofland, MD, PhD, ${ }^{\mathrm{b}}$ Jolien W. Roos-Hesselink, MD, PhD, ${ }^{\mathrm{c}}$ and \\ Ad J. J. C. Bogers, MD, $\mathrm{PhD}^{\mathrm{a}}$
}

Objective: The objective of our study was to report on the total experience in thoracic aortic surgery over a 40-year time period for a single institution.

\begin{abstract}
Methods: All 1075 patients who underwent surgery for thoracic aortic pathology from 1972 to 2011 ( $n=1159)$ were included. Patient, procedural, and follow-up information was obtained from hospital records and the civil registry. Patients were grouped into 4 categories: acute type A dissection $(n=261)$, other ascending aortic/arch surgery $(n=626)$, descending aortic surgery $(n=175)$, and thoracoabdominal surgery $(n=97)$. Risk factors for early and late mortality and the incidence of reoperations were analyzed.
\end{abstract}

Results: The annual number of operations increased significantly over time. In all 4 patient groups, early mortality (in hospital or within 30 days of operation) decreased significantly over time to $15.3 \%$ in group $1,1.9 \%$ in group $2,0 \%$ in group 3 , and $10.5 \%$ in group 4 during the contemporary time period 2007 to 2011 . Overall actuarial survival was $54.3 \%$ (95\% confidence interval, 50.7-57.9) after 10 years and $27.8 \%$ (95\% confidence interval, 26.4-38.3) after 20 years. Late survival improved over time, but was reduced compared with the general population and was related predominantly to preexisting risk factors. In 80 patients, 111 reoperations were necessary, most frequently in group 1 patients and in patients with connective tissue disease.

Conclusions: Thoracic aortic operations were performed increasingly during a 40 -year time period. Early mortality decreased and late survival increased significantly in all patient groups. A significant proportion of patients required multiple operations. (J Thorac Cardiovasc Surg 2014;147:332-43)

Thoracic aortic aneurysm is a frequently encountered condition, potentially leading to lethal complications or serious morbidity. ${ }^{1-3}$ The exact prevalence of thoracic aortic aneurysms is not known. In the United States, aortic aneurysms were ranked 19 in the 2007 mortality statistics, with 13,000 deaths $(0.5 \%$ of all deaths $) .{ }^{4}$ When dissection or rupture occurs as complication of a thoracic aneurysm, emergency surgical treatment is most often the only available option to save a patient's life. Because these emergency operations have considerable operative mortality and complication rates, and because patients might be confronted with potential long-term consequences, elective surgery even in asymptomatic patients with aortic dilatation is recommended in recent guidelines. ${ }^{5}$ The aortic dimension warranting operation depends on the underlying diagnosis.

In this setting, surgery of the thoracic aorta has evolved from a small, but high-impact part in terms of mortality and morbidity of the total cardiothoracic surgical workload

From the Departments of Cardio-Thoracic Surgery, ${ }^{\mathrm{a}}$ Anesthesiology, ${ }^{\mathrm{b}}$ and Cardiology, ${ }^{\mathrm{c}}$ Erasmus University Medical Center, Rotterdam, The Netherlands.

Disclosures: Authors have nothing to disclose with regard to commercial support.

Received for publication May 18, 2012; revisions received Oct 20, 2012; accepted for publication Nov 9, 2012; available ahead of print Dec 26, 2012.

Address for reprints: Jos A. Bekkers, MD, PhD, Department of Cardio-Thoracic Sur-

gery, Bd 571, Erasmus University Medical Center Rotterdam, PO Box 2040, 3000

CA Rotterdam, The Netherlands (E-mail: j.a.bekkers@erasmusmc.nl).

0022-5223/\$36.00

Copyright (c) 2014 by The American Association for Thoracic Surgery

http://dx.doi.org/10.1016/j.jtcvs.2012.11.036 to one of the major subspecialties in cardiovascular surgery. In this study, we report our total experience with thoracic aortic surgery since 1972, specifically early patient outcome as well as long-term results in 4 major subgroups. Furthermore, we analyze evolution over time in timing and characteristics of operations and operative results.

\section{METHODS}

From our institutional aortic surgery database, we extracted 1159 consecutive thoracic aortic procedures in 1075 patients between 1972 and 2011. We excluded patients with primary aortic coarctation and patients who underwent aortic root replacement for pure aortic valve pathology (endocarditis, aortic allograft root replacement, or pulmonary autograft replacement for isolated valve pathology) or complex congenital pathology. Patients who underwent thoracic stent-graft procedures were excluded. Patients were categorized into 4 groups: group 1, acute type A dissections; group 2, ascending aortic and/or arch procedures, excluding acute type A dissections; group 3, descending aortic procedures; and group 4 , thoracoabdominal procedures. Institutional review board approval was obtained for this retrospective follow-up study (Medical Ethics Committee no. 2011-064); the institutional review board waived informed consent. The indications for operation are displayed in Table 1. Preoperative patient characteristics are displayed in Table 2. Operations within 24 hours of onset of complaints are classified as acute, operations within 14 days or during the initial hospital admission are classified as urgent. The other operations were elective.

\section{Operation}

Over time, the operations were performed by 17 attending staff surgeons. Over the years, anesthetic and extracorporeal circulation management and preferred surgical procedures evolved. 


$$
\begin{aligned}
& \text { Abbreviations and Acronyms } \\
& \begin{aligned}
\mathrm{CI} & =\text { confidence interval } \\
\mathrm{HR} & =\text { hazard ratio } \\
\mathrm{OR} & =\text { odds ratio } \\
\mathrm{SD} & =\text { standard deviation } \\
\mathrm{TEVAR} & =\text { thoracic endovascular aortic } \\
& \text { replacement }
\end{aligned}
\end{aligned}
$$

Patients with ascending aortic or aortic arch pathology were operated by median sternotomy using cardiopulmonary bypass. Routine arterial cannulation was in the ascending aorta. Alternative arterial cannulation sites (femoral artery or subclavian artery) were used for acute aortic dissections or when otherwise indicated. Venous cannulation was routinely in the right atrium. Deep hypothermia and circulatory arrest were used when indicated. Additional retrograde or antegrade cerebral perfusion was introduced in 1997 and was used in selected cases. In patients who required multiple periods of cardiopulmonary bypass, aortic crossclamping, or circulatory arrest, the total times were calculated by adding these periods. Cold crystalloid cardioplegia was used for cardiac protection. For aortic replacement, we used various types of vascular prostheses. In the current era, we use impregnated vascular grafts (Gelsoft or Gelseal; Vascutek Ltd, Renfrewshire, Scotland, UK). For aortic arch replacement a branched prosthesis (Plexus 4, Vascutek Ltd) with separate revascularization of arch vessels was used, or the arch vessels were implanted using an island technique. ${ }^{6}$

Patients with descending aortic pathology were operated by lateral thoracotomy; patients with thoracoabdominal pathology, by thoracolaparotomy with splitting of the diaphragm. In patients with descending aortic aneurysms, we preferably used a passive shunt until 1983. Thereafter, we used left heart bypass or full bypass with deep hypothermic circulatory arrest. For thoracoabdominal aneurysms, we used the clamp-and-sew technique described by Crawford and colleagues ${ }^{7}$ until 1988. From 1989 to 1999, a full bypass with deep hypothermic circulatory arrest was used exclusively. From 1999, we used preferably a left heart bypass. Selective perfusion of renal arteries and visceral arteries was used in combination with left heart bypass. Spinal cord fluid drainage was introduced in 2002. Intercostal, renal, and visceral arteries were implanted in the vascular prosthesis used when indicated and feasible.

\section{Follow-up}

All patients were monitored at our institution or by their referring cardiologist. We collected information on vital status, reoperations, and complications. In addition, we consulted the municipal civil registries to ascertain vital status of all patients. Valve-related complications were defined according to the 2008 guidelines for reporting morbidity and mortality after cardiac valvular operations. ${ }^{8}$ Early mortality was defined as mortality in hospital or within 30 days of surgery.

The study database was frozen for analysis on December 31, 2011. Follow-up was $99 \%$ complete; 11 patients were lost to follow-up. The mean follow-up duration was 6.0 years (range, 0-35.3 years), with a total follow-up of 6888 patient-years.

\section{Statistical Methods}

Continuous data are presented as mean (standard deviation (SD) and range). Categorical data are presented as proportions. Differences between groups were analyzed using a Student $t$ test or analysis of variance with Bonferroni correction for continuous data and $\chi^{2}$ test for categorical data. Cumulative survival was analyzed using the Kaplan-Meier method. The survival of a patient started at the time of operation and ended at the time of death (event) or at the last follow-up or reoperation (censoring). Comparison of Kaplan-Meier estimates was done using the Tarone-Ware test.
Univariable and multivariable logistic regression analysis (stepwise backward; inclusion criteria, $P \leq .10$; exclusion criteria, $P \geq .10$ ) was used to study determinants of early mortality. The Cox proportional hazards model was used for univariable and multivariable analysis of time-related events. Variables that were tested as potential risk factors for early and late mortality and reoperations are presented in Appendix 1. A $P$ value of $\leq .05$ was considered statistically significant. All testing was performed 2 sided. For all analyses, SPSS 17.0 for Windows statistical software (SPSS, Chicago, Ill) was used.

\section{RESULTS}

During the study period, 1159 consecutive thoracic aortic operations were performed in 1075 patients. Sixty-one patients were operated upon twice; 7 patients, 3 times; and 3 patients, 4 times. Fourteen of 56 patients $(25 \%)$ with Marfan disease or other connective tissue disease underwent multiple operations compared with 4 out of 1019 patients $(5.3 \%)$ without known genetic diseases (odds ratio [OR], 5.8; 95\% confidence interval [CI], 3.0-11.3; $P<.001)$.

Figure 1, $A$, presents the number of operations per year, showing a steady increase of the annual number of procedures over time. Figure $1, B$, presents the distribution of the 4 patient groups over time, showing an increase in ascending aortic aneurysm operations from $23 \%$ to $72 \%$ over time. Figure 1, $C$, presents the distribution of procedures by urgency of operation over time, showing a shift from $68 \%$ acute or urgent operations to $71 \%$ elective operations in the most recent era.

The perioperative data for all operations are shown in Table 1. In group 1, deep hypothermia with circulatory arrest was used in 220 patients ( $84 \%$; mean duration, 49 minutes; $\mathrm{SD}, 35$ minutes), and in group 2 in 346 patients ( $55 \%$; mean duration, 30 minutes; SD, 36 minutes). In group 1, antegrade cerebral perfusion was used in 48 patients $(18 \%$; mean duration, 77 minutes; SD, 44 minutes), and in group 2 in 62 patients ( $10 \%$; mean duration, 83 minutes; SD, 73 minutes).

In 46 patients $(26 \%)$ in group 3, deep hypothermia with circulatory arrest was used with a mean duration of $44 \mathrm{~min}$ utes (SD, 15 minutes). In 47 patients ( $48 \%$ ) in group 4, deep hypothermia with circulatory arrest was used with a mean duration of 51 minutes (SD, 16 minutes).

\section{Early Mortality and Morbidity}

Early mortality occurred in 167 patients $(14.4 \%) ; 146$ patients $(12.6 \%)$ died within 30 days postoperatively. Over time, the early mortality risk decreased from $>50 \%$ to $5 \%$ in recent years (Figure $1, A$ ). Causes of early mortality were bleeding $(n=45)$, cardiac failure $(n=49)$, sepsis/ multiple-organ failure $(\mathrm{n}=30)$, aortic rupture $(\mathrm{n}=13)$, neurologic $(n=17)$, and other causes $(n=13)$. Mortality within 60 days was $14.2 \%$ (164 patients); mortality within 90 days was $15.6 \%$ (180 patients). Figure 2, A, shows the early mortality per patient group and per 5-year time period. In all 4 patient groups, the mortality risk decreased significantly over time. Early mortality in the most recent time 
TABLE 1. Indications for thoracic aortic surgery and procedures performed

\begin{tabular}{|c|c|c|c|c|}
\hline Group & Indication/etiology & $\mathbf{n}$ & Procedure & n \\
\hline \multirow[t]{17}{*}{ Group 1, acute type A dissection $(\mathrm{n}=261)$} & Acute type A dissection & 261 & Ascending aorta & \\
\hline & Idiopathic & 231 & Replacement & 252 \\
\hline & Marfan/CTD & 17 & Repair/patch & 5 \\
\hline & Iatrogenic (CABG/AVR) & 9 & No ascending aortic procedure* & 4 \\
\hline & Iatrogenic (PCI) & 4 & & \\
\hline & & & Aortic arch & \\
\hline & & & No arch procedure & 37 \\
\hline & & & Hemiarch/open distal anastomosis & 187 \\
\hline & & & Replacement & 41 \\
\hline & & & Repair/patch & 1 \\
\hline & & & Aortic valve & \\
\hline & & & Repair/preservation & 177 \\
\hline & & & Mechanical prosthesis & 11 \\
\hline & & & Bioprosthesis & 3 \\
\hline & & & Allograft & 16 \\
\hline & & & Valved conduit & 53 \\
\hline & & & T. David/Yacoub & 1 \\
\hline \multirow[t]{22}{*}{ Group 2, ascending aorta/aortic arch $(\mathrm{n}=626)$} & Chronic type A dissection & 46 & Ascending aorta & \\
\hline & Idiopathic & 42 & Replacement & 591 \\
\hline & Marfan/CTD & 3 & Repair/patch & 21 \\
\hline & Iatrogenic & 1 & No ascending aortic procedure & 14 \\
\hline & Aneurysm & 538 & Aortic arch & \\
\hline & Idiopathic & 430 & No arch procedure & 279 \\
\hline & Marfan/CTD & 40 & Hemiarch/open distal & 283 \\
\hline & Infectious & 10 & Replacement & 48 \\
\hline & Traumatic & 1 & Replacement with elephant trunk & 11 \\
\hline & Iatrogenic & 4 & Repair/patch & 5 \\
\hline & Allograft failure & 4 & Aortic valve & \\
\hline & Autograft failure & 46 & No valve procedure & 136 \\
\hline & False & 2 & Repair & 10 \\
\hline & Takayasu arteriitis & 1 & Mechanical prosthesis & 68 \\
\hline & Other & 42 & Bioprosthesis & 26 \\
\hline & Idiopathic & 4 & Allograft & 67 \\
\hline & Marfan/CTD & 1 & Valved conduit & 283 \\
\hline & Infectious & 5 & T. David/Yacoub & 32 \\
\hline & Traumatic & 2 & Pulmonary autograft & 4 \\
\hline & Allograft failure & 27 & & \\
\hline & Iatrogenic & 2 & & \\
\hline & Aortic arch stenosis & 1 & & \\
\hline \multirow[t]{14}{*}{ Group 3, descending aorta $(n=175)$} & Acute/urgent dissection & 26 & ECC method & \\
\hline & Aneurysm & 115 & No ECC & 49 \\
\hline & Idiopathic & 75 & Passive shunt & 53 \\
\hline & Marfan/CTD & 1 & Left heart bypass & 27 \\
\hline & Postdissection & 20 & Full bypass with DHCA & 46 \\
\hline & Infectious & 6 & Descending aorta & \\
\hline & Traumatic & 10 & Prosthesis & 156 \\
\hline & False aneurysm & 2 & With (partial) arch & 12 \\
\hline & Leiomyosarcoma & 1 & Patch repair & 14 \\
\hline & Traumatic aortic rupture & 34 & With (partial) arch & 2 \\
\hline & & & No descending aortic procedure & 5 \\
\hline & & & Reimplantation & \\
\hline & & & Left subclavian artery & 13 \\
\hline & & & Intercostal arteries & 7 \\
\hline
\end{tabular}


TABLE 1. Continued

\begin{tabular}{|c|c|c|c|c|}
\hline Group & Indication/etiology & $\mathbf{n}$ & Procedure & $\mathbf{n}$ \\
\hline \multirow[t]{13}{*}{ Group 4, thoracoabdominal aorta $(\mathrm{n}=97)$} & Aneurysm & 97 & ECC method & \\
\hline & Idiopathic & 71 & No ECC & 13 \\
\hline & Marfan/CTD & 7 & Left heart bypass & 37 \\
\hline & Post-dissection & 17 & Full bypass with DHCA & 47 \\
\hline & Infectious & 1 & Thoracoabdominal aorta & \\
\hline & Traumatic & 1 & Prosthesis, distal anastomosis suprarenal & 12 \\
\hline & & & Prosthesis, distal anastomosis infrarenal & 67 \\
\hline & & & Prosthesis, including bifurcation & 17 \\
\hline & & & No aortic procedure $\ddagger$ & 1 \\
\hline & & & Reimplantation & \\
\hline & & & Left subclavian artery & 2 \\
\hline & & & Intercostal arteries & 62 \\
\hline & & & Visceral/renal arteries & 82 \\
\hline
\end{tabular}

$C T D$, Connective tissue disease; $C A B G$, coronary artery bypass grafting; $A V R$, aortic valve replacement; $P C I$, percutaneous catheter intervention; $E C C$, extracorporeal circulation; $D H C A$, deep hypothermia with circulatory arrest. *Two patients were operated by a lateral thoracotomy approach and 2 patients could not be stabilized on extracorporeal circulation. $\dagger$ Five patients could not be stabilized after thoracotomy. $\ddagger$ One patient could not be stabilized after thoracolaparotomy.

period (2007-2011) was $15.3 \%$ in group $1,1.9 \%$ in group 2 , $0 \%$ in group 3 , and $10.5 \%$ in group 4 . In group 1, independent risk factors for early mortality were earlier year of operation (OR, $0.961 ; 95 \%$ CI, 0.924-0.999; $P=.044)$, collapse as the main presenting symptom (OR, 3.3; $95 \% \mathrm{CI}$, 1.3-8.6; $P=.013$ ), and preoperative resuscitation (OR, $4.7 ; 95 \%$ CI, $1.0-20.9 ; P=.044$ ). In group 2 , independent predictors for early mortality were earlier year of operation (OR, 0.852; 95\% CI, 0.812-0.895; $P<.001$ ), older patient age (OR, 1.032; 95\% CI, 1.008-1.056; $P=.008$ ); higher Euroscore (OR, 1.047; 95\% CI, 1.017-1.077; $P=.002$ ), longer cardiopulmonary bypass time (OR, $1.006 ; 95 \% \mathrm{CI}$, $1.003-1.009 ; P<.001)$, and the use of circulatory arrest (OR, 3.4; 95\% CI, 1.1-10.4; $P=.029$ ). In group 3, independent predictors for early mortality included earlier year of operation (OR, 0.944; 95\% CI, 0.898-0.995; $P=.026$ ), older patient age (OR, 1.053; 95\% CI, 1.011-1.085; $P=.001$ ), emergency operation (OR, $0.2 ; 95 \% \mathrm{CI}$, $0.1-0.6 ; P=.001$ ), and postoperative renal dialysis (OR, $8.4 ; 95 \% \mathrm{CI}, 1.7-41.6 ; P=.009)$. Prior aortic surgery (OR, 0.1; 95\% CI, 0.0-0.9; $P=.038$ ) was associated with a reduced early mortality. In group 4 , the use of left heart bypass was associated with reduced early mortality (OR, $0.1 ; 95 \% \mathrm{CI}, 0.0-0.5 ; P=.005$ ) whereas postoperative renal dialysis (OR, 8.8; 95\% CI, 2.2-35.2; $P=.002)$ was an independent predictor of early mortality. More details of the univariable and multivariable analysis of risk factors for early mortality are presented in Appendix 2.

Table 3 presents postoperative complications by patient group for 1972 to 2006 compared with the current era. Early mortality in groups 2,3 , and 4 ; intensive care unit stay of $>2$ days in group 2; and ventilatory support more than 1 day in groups 1,2, and 3 was less in the current era compared with 1972 to 2006. In groups 1 and 2, the overall stroke rate was $11.9 \%$ and $3.2 \%$, respectively, with no difference with regard to whether circulatory arrest was used $(P=.552$ and $P=.185$, respectively).The duration of circulatory arrest or the use of antegrade cerebral perfusion did not influence the postoperative stroke rate. The overall paraplegia rates in groups 3 and 4 were $6.2 \%$ and $19.6 \%$, respectively, and were $0 \%$ and $6 \%$, respectively, for patients operated since 2008 .

\section{Late Survival}

During follow-up, an additional 330 patients died. Causes of late death were cardiac in 67 patients, aortic or vascular related in 33 patients, malignancy in 32 patients, neurologic in 7 patients, and other or unknown causes in 191 patients.

Overall cumulative survival (including early mortality) was $54.3 \%(95 \% \mathrm{CI}, 50.7-57.9)$ after 10 years and 27.8\% (95\% CI, 22.6-32.9) after 20 years (Figure 2, B). Figure 2, $C$, depicts late survival by decade, showing an evident improvement of late survival over time except during the first 2 decades. For the 996 hospital survivors, late survival was $63.2 \%(95 \% \mathrm{CI}, 59.3-67.1)$ after 10 years and 32.3 (95\% CI, 26.4-38.3) after 20 years. This was clearly impaired compared with the age-matched Dutch population (Figure 2,D). Figure 2, E, depicts the late survival of hospital survivors per group. Survival of patients with ascending aortic/aortic arch aneurysms operated after 2000 was $75.8 \%$ at 10 years, which is still reduced in comparison to the $88.0 \%$ of an age-matched Dutch male in the general population (Figure 2, F).

In group 1, independent risk factors for late mortality were earlier year of operation (Hazard Ratio [HR], 0.960; 95\% CI, 0.922-0.998; $P=.041$ ), older patient age (HR, 1.046; 95\% CI, $1.023-1.069 ; P<.001)$, preoperative obstructive pulmonary disease (HR, $4.2 ; 95 \%$ CI, 1.9-9.3; $P<.001$ ), higher preoperative creatinine levels (HR, $1.003 ; 95 \%$ CI, $1.002-1.005 ; P<.001)$, aortic arch replacement (HR, 2.9; 95\% CI, 1.2-6.9; $P=.015)$, and reduced left 
TABLE 2. Preoperative patient characteristics

\begin{tabular}{|c|c|c|c|c|c|c|}
\hline Characteristic & Total $(n=1159)$ & $\begin{array}{c}\text { Group 1, } \\
\text { acute type A } \\
(\mathbf{n}=\mathbf{2 6 1})\end{array}$ & $\begin{array}{c}\text { Group 2, } \\
\text { asc an/chron } \\
\text { type A diss } \\
(\mathbf{n}=626)\end{array}$ & $\begin{array}{c}\text { Group 3, } \\
\text { descending } \\
(n=175)\end{array}$ & $\begin{array}{l}\text { Group 4, } \\
\text { thor-abd } \\
(n=97)\end{array}$ & $\boldsymbol{P}$ \\
\hline $\begin{array}{l}\text { Mean age, years, } \mathrm{n}(\mathrm{SD} \text {, } \\
\text { range) }\end{array}$ & $56(16,9-83)$ & $58(13,19-83)$ & $53(17,9-83)$ & $57(16,15-79)$ & $64(9,34-75)$ & $<.001$ \\
\hline $\begin{array}{l}\text { Male-to-female ratio, } \\
\mathrm{n}(\% / \%)\end{array}$ & $794 / 365(68 / 32)$ & $166 / 95(64 / 36)$ & 435/191 (70/30) & $134 / 41(77 / 23)$ & $59 / 38(61 / 39)$ & .011 \\
\hline $\begin{array}{l}\text { Creatinine, } \mu \mathrm{mol} / \mathrm{L} \\
\mathrm{n}(\mathrm{SD}, \text { range }), \mathrm{n}=1109\end{array}$ & $97(54,25-861)$ & $115(84,25-861)$ & $88(31,27-367)$ & $103(58,41-613)$ & $98(45,39-385)$ & $<.001$ \\
\hline $\begin{array}{l}\text { Prior cardiac surgery/PCI, } \\
\mathrm{n}(\%)\end{array}$ & $226(19.5)$ & $32(12.3)$ & $170(27.2)$ & $10(5.7)$ & $14(14.4)$ & $<.001$ \\
\hline Prior aortic surgery, n (\%) & $193(16.7)$ & $13(5.0)$ & $116(18.7)$ & $32(18.3)$ & $32(33.0)$ & $<.001$ \\
\hline Hypertension, n (\%) & $504(43.5)$ & $138(52.9)$ & $216(34.5)$ & $83(47.4)$ & $67(69.1)$ & $<.001$ \\
\hline COPD, n (\%) & $100(8.6)$ & $18(6.9)$ & $46(7.3)$ & $19(10.9)$ & $17(17.5)$ & .004 \\
\hline Prior CVA, n (\%) & $39(3.4)$ & $4(1.5)$ & $27(4.3)$ & $3(1.7)$ & $5(5.2)$ & .077 \\
\hline Diabetes mellitus, n (\%) & $31(2.7)$ & $4(1.5)$ & $18(2.9)$ & $5(2.9)$ & $4(4.1)$ & .631 \\
\hline $\begin{array}{l}\text { Prior myocardial infarction, } \\
\mathrm{n}(\%)\end{array}$ & $60(5.2)$ & $14(5.4)$ & $34(5.4)$ & $6(3.4)$ & $6(6.2)$ & .707 \\
\hline \multicolumn{7}{|l|}{ Systolic LVF, n (\%), n = 631} \\
\hline Good & $476(75.4)$ & $100(88.5)$ & $326(71.2)$ & $18(85.7)$ & $32(82.1)$ & .009 \\
\hline Impaired & $96(15.2)$ & $6(5.3)$ & 85 (18.6) & - & $5(12.8)$ & \\
\hline Moderate/Bad & $59(9.4)$ & $7(6.2)$ & $47(10.2)$ & $3(14.3)$ & $2(5.1)$ & \\
\hline $\begin{array}{l}\text { Logistic Euroscore, mean } \\
\text { (SD, range) }\end{array}$ & $14.6(11.2,5-88)$ & $21.1(14.4,5-79)$ & $12.6(9.5,5-88)$ & $12.3(8.6,5-62)$ & $13.8(8.2,5-40)$ & $<.001$ \\
\hline \multicolumn{7}{|l|}{ THAA extent, $\mathrm{n}(\%)$} \\
\hline 1 & & & & & $6(6.2)$ & \\
\hline 2 & & - & - & - & $58(59.8)$ & \\
\hline 3 & & & & & $32(33)$ & \\
\hline 4 & & & & & $1(1.0)$ & \\
\hline \multicolumn{7}{|l|}{ Urgency of operation, $\mathrm{n}(\%)$} \\
\hline Acute, $<24 \mathrm{~h}$ & $336(29.0)$ & $243(93.1)$ & $27(4.3)$ & $61(34.9)$ & $5(5.2)$ & $<.001$ \\
\hline Urgent, $<14 \mathrm{~d}$ & $183(15.8)$ & $18(6.9)$ & $99(15.8)$ & $44(25.1)$ & $22(22.7)$ & \\
\hline Elective & $640(55.2)$ & - & $500(79.9)$ & $70(40.0)$ & $70(72.2)$ & \\
\hline
\end{tabular}

asc an/chron type A diss, ascending aortic aneurysm/chronic dissection; thor-abd, thoraco-abdominal aneurysm; $S D$, standard deviation; $P C I$, percutaneous catheter intervention; $C O P D$, chronic obstructive pulmonary disease; $C V A$, cerebrovascular accident; $L V F$, left ventricular function; THAA, thoracoabdominal aneurysm.

ventricular function (HR, 6.2; 95\% CI, 1.9-20.2; $P=.002$ ). In group 2, independent predictors for late mortality were earlier year of operation (OR, 0.937; 95\% CI, 0.913$0.962 ; P<.001)$, older patient age (HR, $1.051 ; 95 \% \mathrm{CI}$, 1.036-1.066; $P<.001$ ), higher preoperative creatinine levels (OR, $1.005 ; 95 \%$ CI, 1.000-1.010; $P=.031$ ), higher Euroscore (OR, 1.024; 95\% CI, 1.004-1.045; $P=.021$ ), aortic arch replacement (HR, 1.9; 95\% CI, 1.1-3.5; $P=.026$ ), and postoperative myocardial infarction (HR, 5.6; 95\% CI, 2.3-13.2; $P<.001)$. In group 3, independent predictors for late mortality included older patient age (HR, 1.060; 95\% CI, 1.041-1.080; $P<.001)$ and preoperative obstructive pulmonary disease (HR, $1.9 ; 95 \%$ CI, $1.0-$ $3.5 ; P=.041)$; in group 4, older patient age (OR, 1.097; 95\% CI, 1.041-1.135; $P=.001)$ was an independent predictor of late mortality. More details of the univariable and multivariable analysis of risk factors for late mortality are presented in Appendix 3.

\section{Reoperations}

Eighty patients underwent 111 reoperations. Appendix 4 presents an overview of these reoperations per patient group. In group 1 (acute type A dissection), most reoperations were for aortic valve incompetence in repaired or preserved native aortic valves at the primary operation $(n=14)$ or structural valve deterioration after allograft implantation $(\mathrm{n}=5)$. The rate of aortic valve reoperation was increased in patients with preoperative severe aortic valve insufficiency who had their aortic valves preserved (HR, 2.9; $95 \%$ CI, 1.1-8.2; $P=.049$ ). Reoperations for distal aortic pathology, related to the chronic rest-dissection after repaired type A dissection, were more frequent in patients with a connective tissue disease or with type 1 dissection versus type 2 dissection, although not significant. The freedom from proximal reoperation was $84.6 \%$ at 10 years and $71.4 \%$ at 15 years. The freedom from distal aortic reoperations was $90.2 \%$ after 10 years and $83.7 \%$ after 15 years. In 


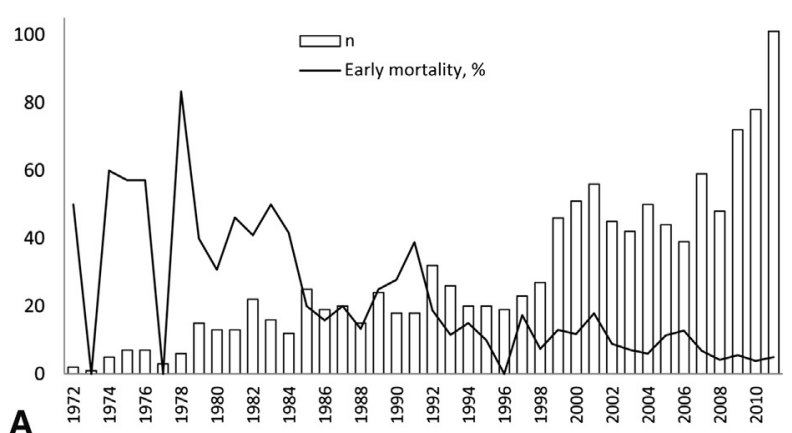

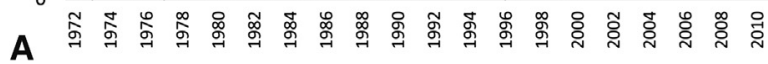
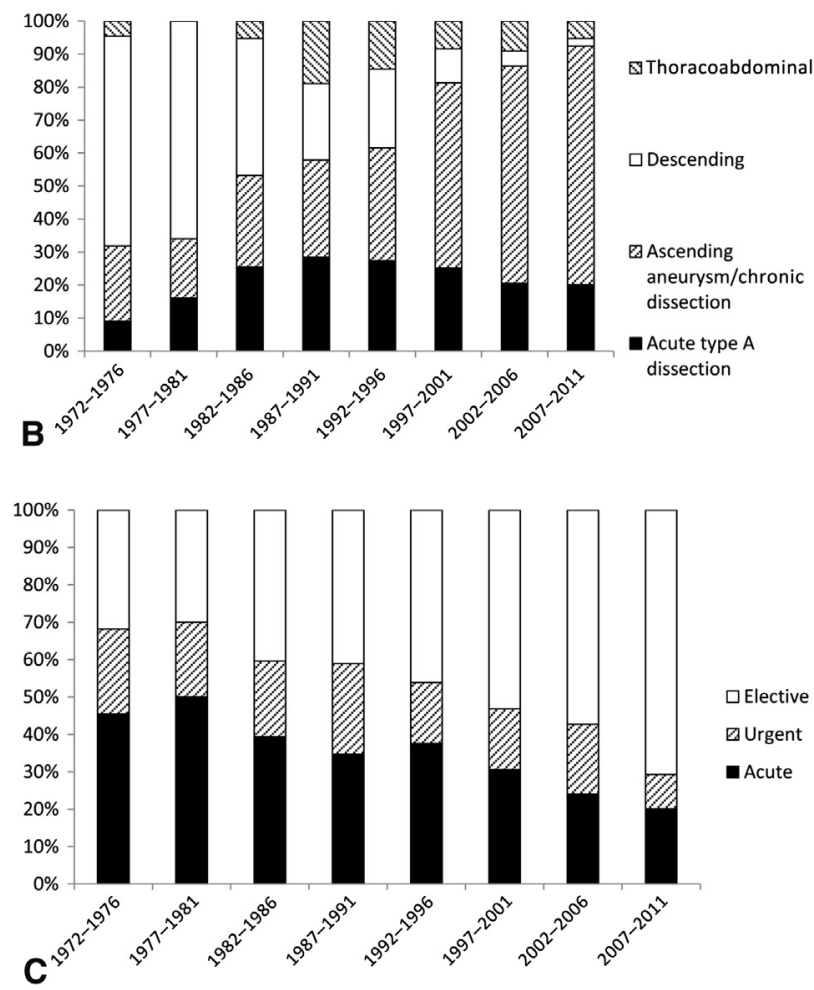

FIGURE 1. A-C, Overview of number of operations and early mortality per year (A) distribution over 4 patients groups per 5-year time period (B) and distribution over 3 urgency classes per 5-year time period (C).

the other patient groups, reoperations on the aorta were less frequent. In group 2 (chronic aortic aneurysm/dissection), reoperations were more frequent in patients with Marfan disease or other known connective tissue diseases with an HR for proximal reoperation of 3.5 (95\% CI, 1.5-8.5; $P=.005)$ and an HR for distal reoperation of $6.2(95 \%$ CI, 2.7-14.5; $P<.001)$. Furthermore, distal reoperations were more frequent after elephant trunk aortic arch replacement. In group 3 (descending aorta), most reoperations were for abdominal aortic pathology.

\section{DISCUSSION}

In this article, we provide an overview of all thoracic aortic operations performed in our center between 1972 and
2011. The annual number of operations increased during this 40 -year time period to about $10 \%$ of the annual caseload in our department. We demonstrate a shift from $70 \%$ emergency or urgent operations to $70 \%$ elective surgeries, and a shift from predominantly descending aortic operations to $70 \%$ ascending aortic or aortic arch operations, confirming observations made by Achneck and associates. ${ }^{9}$ Olsson and colleagues ${ }^{10}$ also demonstrated an increase in prevalence of thoracic aortic disease and number of operations performed between 1987 and 2002 in Sweden. The increased knowledge of inherited conditions has led to further recommendations for early intervention at only slightly abnormal aortic diameters in patients with specific gene mutations $^{11,12}$ and might play an additional role in the increase of the number of operations performed.

We observed a decrease in descending aortic surgery. Thoracic endovascular aortic replacement (TEVAR) is increasingly used as the first-choice therapy for descending aortic aneurysms ${ }^{5}$ and traumatic aortic rupture with equal or even lower early mortality and complications. ${ }^{13,14}$ However, long-term results of TEVAR therapy are still unknown, and randomized trials comparing open surgery and TEVAR are lacking, making definitive conclusions on the merits of TEVAR impossible. ${ }^{15}$

Over time, early mortality decreased significantly from $>50 \%$ early in the series in all 4 patients groups to $15 \%$ for acute type A dissections, 1.9\% for other ascending aortic and arch pathology, $0 \%$ for descending aortic aneurysms, and $10.5 \%$ for thoracoabdominal aneurysms in the most recent era of 2007 to 2011 . These recent early mortality rates are in line with other published series and outline the safety of thoracic aortic surgery in the current era. For acute type A dissections, the International Registry of Acute Aortic Dissections reports an overall in-hospital mortality of $23.9 \%$ for patients operated on between 1996 and 2003. ${ }^{16}$ Achneck and colleagues ${ }^{9,17}$ report a mortality of $3.0 \%$ in elective ascending aorta or arch surgery, a mortality of $2.9 \%$ for elective descending aortic surgery, and a mortality of $11.9 \%$ for elective thoracoabdominal aortic surgery. Estrera and colleagues ${ }^{18}$ report a 30-day mortality of $7.3 \%$ and an incidence of $2.3 \%$ neurologic deficit in 300 patients operated for descending aortic aneurysms.

In a previous study on acute type A dissection, excluding patients with traumatic or iatrogenic dissections, we found the reduction in 30-day mortality to be related to technical improvement in the conduct of the operation. ${ }^{19}$ The use of circulatory arrest combined with an open distal anastomosis and the use of biologic glue were associated with a lower early mortality.

In descending aortic surgery, the reduction in operative mortality might be associated with major changes in operative indications. Acute surgery for traumatic aortic rupture or complicated dissection is currently replaced by 

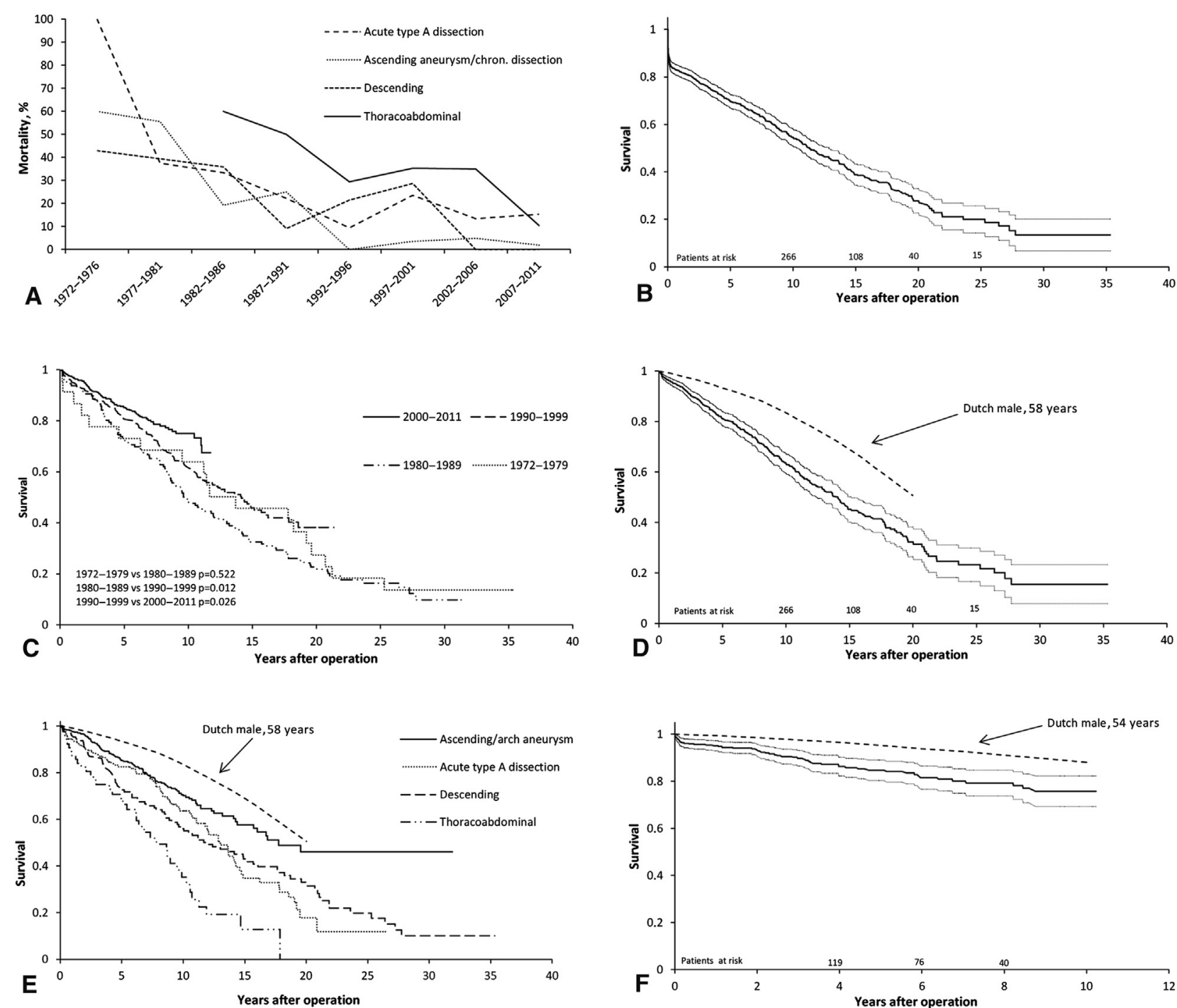

FIGURE 2. Early mortality per patient group and per 5 year time period. A, Overall survival of 1159 patients after thoracic aortic surgery between 1972 and 2011 with $95 \%$ confidence interval (B) overall survival after thoracic aortic surgery per decade (C) survival of 996 hospital survivors after thoracic aortic surgery with $95 \%$ confidence interval compared with the survival of a 58-year-old Dutch male (D) survival of hospital survivors per group (E) survival of 417 patients operated for ascending aortic or aortic arch aneurysms between 2000 and 2011 with 95\% confidence interval compared with a 54-year-old Dutch male (F).

endovascular procedures. On the other hand, open surgery is currently indicated for patients with a chronic dissection or unfavorable anatomy not amenable to TEVAR procedures. In our patient group with predominantly chronic dissections, or contraindications for TEVAR, we found no mortality or paraplegia during the last 10 years. Prior aortic surgery was associated with a lower early mortality; emergency operations were associated with a higher early mortality.

In the thoracoabdominal aneurysm group with $93 \%$ extent 2 or 3 patients, we found the improvement in early mortality to be related to changes in operative technique. The currently preferred technique - using left heart bypass, visceral perfusion, and cerebrospinal fluid drainage-resulted in a significantly lower mortality as described by others. ${ }^{20}$ In this group of patients, we observed a decrease in the paraplegia rate to $6 \%$ since 2008 , in line with other contemporary series reported. ${ }^{21}$

Information on late survival after thoracic aortic surgery is rare. Kouchoukos and colleagues ${ }^{22}$ found 10 -year survival rates of $40 \%$ to $65 \%$ after acute ascending aortic dissection, $57 \%$ to $75 \%$ after other ascending aortic or arch operations, and $32 \%$ to $37 \%$ after thoracoabdominal aortic operations. Olsson and colleagues ${ }^{10}$ found an overall survival of hospital survivors of $57 \%$ at 10 years and $43 \%$ at 15 years in 2455 patients operated for various types of thoracic aortic disease between 1987 and 2002. In our series, we demonstrate an overall long-term survival of $54 \%$ at 
TABLE 3. Postoperative complications

\begin{tabular}{|c|c|c|c|c|c|c|c|c|}
\hline \multirow[b]{2}{*}{ Complication } & \multicolumn{4}{|c|}{ Era 1972 to $2006(n=801)$} & \multicolumn{4}{|c|}{ Era 2007 to $2011(n=358)$} \\
\hline & $\begin{array}{c}\text { Group 1 } \\
(\mathrm{n}=189)\end{array}$ & $\begin{array}{l}\text { Group 2 } \\
(\mathbf{n}=367)\end{array}$ & $\begin{array}{r}\text { Group } 3 \\
(\mathrm{n}=167)\end{array}$ & $\begin{array}{l}\text { Group } 4 \\
(n=78)\end{array}$ & $\begin{array}{l}\text { Group 1 } \\
(\mathrm{n}=72)\end{array}$ & $\begin{array}{l}\text { Group } 2 \\
(\mathrm{n}=259)\end{array}$ & $\begin{array}{c}\text { Group } 3 \\
(\mathbf{n}=\mathbf{8})\end{array}$ & $\begin{array}{l}\text { Group } 4 \\
(n=19)\end{array}$ \\
\hline Early mortality & $40(21.2 \%)$ & $31(8.4 \%)$ & $47(26.6 \%)$ & $31(39.7 \%)$ & $11(15.3 \%)$ & $5(1.9 \%)^{*}$ & $0 *$ & $2(10.5 \%)$ \\
\hline \multicolumn{9}{|l|}{ Intensive care unit stay } \\
\hline Mean, days (SD) & $8.2(10.4)$ & $3.4(5.7)$ & $5.8(9.5)$ & $15.0(28.2)$ & $8.2(12.0)$ & $2.3(5.6)$ & $3.1(3.9)$ & $12.7(12.7)$ \\
\hline$>2 \mathrm{~d}$ & $136(72.0 \%)$ & $114(31.1 \%)$ & $79(46.1 \%)$ & $61(78.2 \%)$ & $54(75.0 \%)$ & $33(12.7 \%)^{*}$ & $2(25.0 \%)$ & $18(94.7 \%)$ \\
\hline \multicolumn{9}{|l|}{ Ventilation } \\
\hline Mean, days, (SD) & $6.2(9.3)$ & $2.1(4.8)$ & $4.4(8.6)$ & $12.2(31.2)$ & $6.1(11.9)$ & $1.8(5.2)$ & $2.0(2.8)$ & $9.3(12.2)$ \\
\hline$>1 \mathrm{~d}$ & $153(81.0 \%)$ & $136(37.1 \%)$ & $121(74.9 \%)$ & $64(82.1 \%)$ & $42(58.3 \%)^{*}$ & $21(8.1 \%)^{*}$ & $1(12.5 \%)^{*}$ & $16(84.2 \%)$ \\
\hline Tracheostomy & $13(6.9 \%)$ & $7(1.9 \%)$ & $19(11.4 \%)$ & $13(16.7 \%)$ & $5(6.9 \%)$ & $2(0.8 \%)$ & 0 & $1(5.3 \%)$ \\
\hline Myocardial infarction & $12(6.3 \%)$ & $10(2.7 \%)$ & $2(1.2 \%)$ & $4(5.1 \%)$ & $1(1.4 \%)$ & $4(1.5 \%)$ & 0 & 0 \\
\hline $\begin{array}{l}\text { Renal dysfunction } \\
\quad(\text { creatinine }>150 \mu \mathrm{mol} / \mathrm{L})\end{array}$ & $56(29.6 \%)$ & $34(9.3 \%)$ & $48(28.7 \%)$ & $43(55.1 \%)$ & $25(34.7 \%)$ & $22(8.5 \%)$ & $2(25.0 \%)$ & $9(47.4 \%)$ \\
\hline Dialysis & $20(10.6 \%)$ & $8(2.2 \%)$ & $12(7.2 \%)$ & $11(14.1 \%)$ & $9(12.5 \%)$ & $5(1.9 \%)$ & 0 & $5(26.3 \%)$ \\
\hline Atrial fibrillation & $56(29.6 \%)$ & $114(31.1 \%)$ & $12(7.2 \%)$ & $14(17.9 \%)$ & $20(27.8 \%)$ & $71(27.4 \%)$ & 0 & $2(10.5 \%)$ \\
\hline Cerebrovascular accident & $25(13.2 \%)$ & $15(4.1 \%)$ & $12(7.2 \%)$ & $6(7.7 \%)$ & $6(8.3 \%)$ & $5(1.9 \%)$ & $2(25.0 \%)$ & 0 \\
\hline Paraplegia & $6(2.2 \%)$ & 0 & $11(6.3 \%)$ & $16(20.5 \%)$ & $1(1.4 \%)$ & 0 & 0 & $3(15.8 \%)$ \\
\hline Recurrent nerve paralysis & $8(3.1 \%)$ & $10(1.6 \%)$ & $24(13.7 \%)$ & $10(10.3 \%)$ & 0 & $5(1.9 \%)$ & $3(37.5 \%)$ & $3(15.8 \%)$ \\
\hline Delirium & $46(17.6 \%)$ & $28(4.5 \%)$ & $7(4.0 \%)$ & $18(18.6 \%)$ & $21(29.2 \%)$ & $17(6.6 \%)$ & 0 & $3(15.8 \%)$ \\
\hline
\end{tabular}

$S D$, Standard deviation. $* P<.05$ comparing era 2007 to 2011 with era 1972 to 2006

10 years and $28 \%$ at 20 years. The late survival for hospital survivors was $63 \%$ at 10 years and $32 \%$ at 15 years, and improved over time. This late survival was reduced when compared with survival in the normal population. Late survival was reduced after thoracoabdominal aortic surgery related predominantly to general risk factors for reduced survival. We found the survival of contemporary patients, operated since 2000 , with ascending aortic or aortic arch aneurysms to be $76 \%$ at 10 years, compared with $88 \%$ survival at 10 years with the age-matched general population. This reduction in 10-year survival has to be weighed against the risk of a fatal outcome in untreated aortic aneurysms. Davies and colleagues $^{23}$ estimate the yearly rate of rupture, dissection, or death to be $6 \%$ for aneurysms 5.0 to $5.9 \mathrm{~cm}$ and $15 \%$ for aneurysms $>6 \mathrm{~cm}^{23}$ They found the 5-year survival of nonoperated patients to be $54 \%$, which is clearly inferior than the survival of operated patients. This information can be used in advising patients with asymptomatic aneurysms and may be used to lower the threshold for elective aortic replacement.

Aortic disease may be present in multiple segments of the aorta, especially in patients with Marfan disease or other genetic aortic diseases. In our series, 69 of 1075 patients $(6.4 \%)$ underwent multiple operations. In patients with genetic diseases, multiple operations were 5-fold more frequent. Multiple operations in patients after acute type A dissection are reported in $10 \%$ to $15 \%$ of patients, with a freedom from reoperation of $71 \%$ to $79 \%$ after 10 years. $^{24,25}$ We recently found an increased rate of aortic valve reoperations in patients presenting with severe aortic insufficiency preoperatively who had their valves preserved or after allograft implantation. ${ }^{19}$ In the current series, we found 48 reoperations on the aortic valve or the proximal aorta, with a freedom from proximal reoperation of $85 \%$ at 10 years and $72 \%$ at 15 years. Freedom of distal reoperation after acute type A aortic dissection was $90 \%$ at 10 years and $84 \%$ at 15 years. Reoperations after descending aortic replacement were most frequently for abdominal aortic aneurysms. Reoperations after ascending aortic surgery, other than for acute dissections or thoracoabdominal aortic surgery, were less frequent.

\section{Study Limitations}

Our study presents a retrospective single-center experience of a 40-year time period. Operations have been performed by 17 different surgeons. During this period, changes in patient population, operative indications, diagnostics, operative and anesthesiologic management, and conduct of cardiopulmonary bypass have occurred that can only be evaluated in part. Although follow-up information on the vital status of patients is nearly complete, exact information on the causes of death is not available.

\section{CONCLUSIONS}

Thoracic aortic surgery increased in numbers of operations performed during a 40-year period at our institution. There has been a shift from predominantly emergency or urgent operations to elective procedures, and from descending aortic to ascending aortic operations. Early mortality decreased significantly over time for all patients groups. Long-term survival improved significantly over time, although was still being reduced compared with the general population. A significant proportion of patients required multiple operations, especially patients with Marfan disease 
or other connective tissue diseases, and patients operated for acute ascending aortic dissection.

\section{References}

1. Elefteriades JA, Farkas EA. Thoracic aortic aneurysm clinically pertinent controversies and uncertainties. J Am Coll Cardiol. 2010;55:841-57.

2. Patel HJ, Deeb GM. Ascending and arch aorta: pathology, natural history, and treatment. Circulation. 2008;118:188-95.

3. Booher AM, Eagle KA. Diagnosis and management issues in thoracic aortic aneurysm. Am Heart J. 2011;162:38-46.

4. Centers for Disease Control and Prevention. Broker version 8.1 (build 1366). Available at: http://webappa.cdc.gov/cgi-bin/broker.exe. Accessed December 5,2012 .

5. Hiratzka LF, Bakris GL, Beckman JA, Bersin RM, Carr VF, Casey DE Jr, et al. $2010 \mathrm{ACCF} / \mathrm{AHA} / \mathrm{AATS} / \mathrm{ACR} / \mathrm{ASA} / \mathrm{SCA} / \mathrm{SCAI} / \mathrm{SIR} / \mathrm{STS} / \mathrm{SVM}$ guidelines for the diagnosis and management of patients with thoracic aortic disease: a report of the American College of Cardiology Foundation/American Heart Association Task Force on Practice Guidelines, American Association for Thoracic Surgery, American College of Radiology, American Stroke Association, Society of Cardiovascular Anesthesiologists, Society for Cardiovascular Angiography and Interventions, Society of Interventional Radiology, Society of Thoracic Surgeons, and Society for Vascular Medicine. Circulation. 2010;121:e266-369.

6. Kazui T, Washiyama N, Muhammad BA, Terada H, Yamashita K, Takinami M, et al. Total arch replacement using aortic arch branched grafts with the aid of antegrade selective cerebral perfusion. Ann Thorac Surg. 2000;70:3-8; discussion 9.

7. Crawford ES, Walker HS III, Saleh SA, Normann NA. Graft replacement of aneurysm in descending thoracic aorta: results without bypass or shunting. Surgery. 1981;89:73-85.

8. Akins CW, Miller DC, Turina MI, Kouchoukos NT, Blackstone EH, Grunkemeier GL, et al. Guidelines for reporting mortality and morbidity after cardiac valve interventions. J Thorac Cardiovasc Surg. 2008;135:732-8.

9. Achneck HE, Rizzo JA, Tranquilli M, Elefteriades JA. Safety of thoracic aortic surgery in the present era. Ann Thorac Surg. 2007;84:1180-5; discussion 5.

10. Olsson C, Thelin S, Stahle E, Ekbom A, Granath F. Thoracic aortic aneurysm and dissection: increasing prevalence and improved outcomes reported in a nationwide population-based study of more than 14,000 cases from 1987 to 2002 . Circulation. 2006;114:2611-8.

11. Caglayan AO, Dundar M. Inherited diseases and syndromes leading to aortic aneurysms and dissections. Eur J Cardiothorac Surg. 2009;35:931-40.

12. van de Laar IM, van der Linde D, Oei EH, Bos PK, Bessems JH, BiermaZeinstra SM, et al. Phenotypic spectrum of the SMAD3-related aneurysms-osteoarthritis syndrome. J Med Genet. 2012;49:47-57.

13. Xenos ES, Minion DJ, Davenport DL, Hamdallah O, Abedi NN, Sorial EE, et al. Endovascular versus open repair for descending thoracic aortic rupture: institutional experience and meta-analysis. Eur J Cardiothorac Surg. 2009;35:282-6.

14. Walsh SR, Tang TY, Sadat U, Naik J, Gaunt ME, Boyle JR, et al. Endovascular stenting versus open surgery for thoracic aortic disease: systematic review and meta-analysis of perioperative results. J Vasc Surg. 2008;47:1094-8.

15. Cao CQ, Bannon PG, Shee R, Yan TD. Thoracic endovascular aortic repair: indications and evidence. Ann Thorac Cardiovasc Surg. 2011;17:1-6.

16. Rampoldi V, Trimarchi S, Eagle KA, Nienaber CA, Oh JK, Bossone E, et al. Simple risk models to predict surgical mortality in acute type A aortic dissection: the International Registry of Acute Aortic Dissection score. Ann Thorac Surg. 2007; 83:55-61.

17. Acher C, Wynn M. Outcomes in open repair of the thoracic and thoracoabdominal aorta. J Vasc Surg. 2010;52:3S-9S

18. Estrera AL, Miller CC III, Chen EP, Meada R, Torres RH, Porat EE, et al. Descending thoracic aortic aneurysm repair: 12-year experience using distal aortic perfusion and cerebrospinal fluid drainage. Ann Thorac Surg. 2005;80:1290-6; discussion 1296.

19. Bekkers JA, Bol Raap G, Takkenberg JJM, Bogers AJJC. Acute type A aortic dissection: long-term results and reoperations. Eur J Cardiothorac Surg. December 4, 2012. http://dx.doi.org/10.1093/ejcts/ezs342.
20. Schepens M, Dossche K, Morshuis W, Heijmen R, van Dongen E, Ter Beek H, et al. Introduction of adjuncts and their influence on changing results in 402 consecutive thoracoabdominal aortic aneurysm repairs. Eur J Cardiothorac Surg. 2004;25:701-7.

21. LeMaire SA, Price MD, Green SY, Zarda S, Coselli JS. Results of thoracoabdominal aortic aneurysm repair. Ann Cardiothorac Surg. 2012;1:286-92.

22. Kouchoukos NT, Dougenis D. Surgery of the thoracic aorta. N Engl J Med. 1997; 336:1876-88.

23. Davies RR, Goldstein LJ, Coady MA, Tittle SL, Rizzo JA, Kopf GS, et al. Yearly rupture or dissection rates for thoracic aortic aneurysms: simple prediction based on size. Ann Thorac Surg. 2002;73:17-27; discussion 28.

24. Concistre G, Casali G, Santaniello E, Montalto A, Fiorani B, Dell'Aquila A, et al. Reoperation after surgical correction of acute type A aortic dissection: risk factor analysis. Ann Thorac Surg. 2012;93:450-5.

25. Kirsch M, Soustelle C, Houel R, Hillion M, Loisance D. Risk factor analysis for proximal and distal reoperations after surgery for acute type A aortic dissection. J Thorac Cardiovasc Surg. 2002;123:318-25.

\section{APPENDIX 1. VARIABLES TESTED AS POTENTIAL RISK FACTORS FOR EARLY MORTALITY AFTER THORACIC AORTIC SURGERY}

The following variables were tested as potential risk factors for early mortality after thoracic aortic surgery: patient age (continuous variable expressed in years), gender, prior cardiac surgery, prior aortic surgery, prior myocardial infarction, hypertension, chronic obstructive pulmonary disease using medication or forced expiratory volume in 1 second $<70 \%$ than predicted, diabetes mellitus (insulin dependent or noninsulin dependent), prior cerebrovascular accident, dissection type (DeBakey type 1 or 2), etiology (idiopathic or connective tissue disease), main presenting symptom (acute pain, collapse/stroke, dyspnea, other), preoperative cardiac ischemia, malperfusion (cardiac ischemia, acute neurologic deficit, vascular dysfunction, paraplegia or peripheral neurologic deficit), preoperative ventilation support, preoperative shock (systolic blood pressure $<90 \mathrm{~mm}$ $\mathrm{Hg}$ ), preoperative tamponade, preoperative resuscitation, preoperative pericardial drainage, preoperative renal function (serum creatinine, continuous variable expressed in micromoles per liter), systolic left ventricular function (good vs impaired/moderate/bad), urgency of the procedure (within 24 hours, within 14 days after onset of complaints, or elective), logistic Euroscore, year of operation, use of cardiopulmonary bypass (none, passive shunt, left heart bypass, full bypass), cardiopulmonary bypass time (continuous variable expressed in minutes), aortic crossclamp time (continuous variable expressed in minutes), use of circulatory arrest, circulatory arrest time (continuous variable expressed in minutes), postoperative myocardial infarction, postoperative cerebrovascular accident, postoperative renal dysfunction (serum creatinine $>150 \mu \mathrm{mol} / \mathrm{L}$ ), postoperative renal dialysis, and postoperative paraplegia. 
APPENDIX 2. Univariable and multivariable analysis of factors for early mortality

\begin{tabular}{|c|c|c|c|c|c|c|c|c|}
\hline \multirow[b]{2}{*}{ Factor } & \multicolumn{2}{|c|}{ Group 1} & \multicolumn{2}{|c|}{ Group 2} & \multicolumn{2}{|c|}{ Group 3} & \multicolumn{2}{|c|}{ Group 4} \\
\hline & $\begin{array}{c}\text { Univariable } \\
\text { OR }(95 \% \mathrm{CI}) \\
\quad P \text { value }\end{array}$ & $\begin{array}{c}\text { Multivariable } \\
\text { OR }(95 \% \mathrm{CI}) ; \\
\quad P \text { value }\end{array}$ & $\begin{array}{c}\text { Univariable } \\
\text { OR }(95 \% \mathrm{CI}) \\
\quad P \text { value }\end{array}$ & $\begin{array}{c}\text { Multivariable } \\
\text { OR ( } 95 \% \mathrm{CI}) ; \\
\quad P \text { value }\end{array}$ & $\begin{array}{c}\text { Univariable } \\
\text { OR ( } 95 \% \mathrm{CI}) ; \\
\quad P \text { value }\end{array}$ & $\begin{array}{c}\text { Multivariable } \\
\text { OR }(95 \% \mathrm{CI}) ; \\
\quad P \text { value }\end{array}$ & $\begin{array}{c}\text { Univariable } \\
\text { OR ( } 95 \% \mathrm{CI}) \\
\quad P \text { value }\end{array}$ & $\begin{array}{c}\text { Multivariable } \\
\text { OR }(95 \% \mathrm{CI}) ; \\
\quad P \text { value }\end{array}$ \\
\hline Year of operation & $0.962(0.932-0.993) ; .018$ & $\begin{array}{l}0.961(0.924-0.999) \text {; } \\
\quad .044\end{array}$ & $\begin{array}{l}0.887(0.856-0.919) \\
\quad<.001\end{array}$ & $\begin{array}{l}0.852(0.812-0.895) \\
\quad<.001\end{array}$ & $\begin{array}{l}0.928(0.888-0.969) \text {; } \\
\quad .001\end{array}$ & $\begin{array}{l}0.944(0.898-0.993) ; \\
\quad .026\end{array}$ & $\begin{array}{l}0.932(0.882-0.986) ; \\
\quad .014\end{array}$ & \\
\hline Age & & & $\begin{array}{l}1.032(1.008-1.056) ; \\
.008\end{array}$ & $\begin{array}{l}1.039(1.004-1.075) ; \\
.029\end{array}$ & $\begin{array}{l}1.033(1.008-1.059) ; \\
\quad .011\end{array}$ & $\begin{array}{l}1.053(1.022-1.085) \text {; } \\
.001\end{array}$ & & \\
\hline Prior CVA & & & $3.0(1.0-9.4) ; .049$ & & & & & \\
\hline Prior myocardial infarction & & & & & & & $4.3(0.7-24.7) ; .104$ & \\
\hline $\begin{array}{l}\text { Collapse main presenting } \\
\text { symptom }\end{array}$ & $4.1(1.8-9.3) ; .001$ & $3.3(1.3-8.6) ; .013$ & & & & & & \\
\hline Prior aortic surgery & & & & & $0.1(0.0-0.6) ; .010$ & $0.1(0.0-0.9) ; .038$ & & \\
\hline Preoperative shock & & & $10.6(2.4-46.4) ; .002$ & & & & & \\
\hline Preoperative malperfusion & $2.6(1.3-5.2) ; .005$ & & & & & & & \\
\hline $\begin{array}{l}\text { Preoperative ventilatory } \\
\text { support }\end{array}$ & $6.2(2.2-17.6) ; .001$ & & & & & & & \\
\hline Preoperative resuscitation & $6.9(1.9-25.6) ; .004$ & $4.7(1.0-20.9) ; .044$ & & & & & & \\
\hline $\begin{array}{l}\text { Preoperative pericardial } \\
\text { drainage }\end{array}$ & $5.6(1.4-21.8) ; .012$ & & & & & & & \\
\hline Preoperative creatinine & & & $\begin{array}{l}1.014(1.006-1.021) \\
\quad<.001\end{array}$ & & & & & \\
\hline Euroscore & $1.020(1.001-1.040) ; .043$ & $\begin{array}{l}1.024(0.999-1.050) \text {; } \\
\quad .060\end{array}$ & $\begin{array}{l}1.057(1.032-1.083) ; \\
\quad<.001\end{array}$ & $\begin{array}{l}1.047 \text { (1.017-1.077); } \\
.002\end{array}$ & $\begin{array}{l}1.043(1.004-1.083) \text {; } \\
\quad .032\end{array}$ & & & \\
\hline Urgency 1 vs $2-3$ & & & $0.1(0.0-0.2) ;<.001$ & & $\begin{array}{l}0.3(0.2-0.6) \text {; } \\
.001\end{array}$ & $0.2(0.1-0.6) ; .001$ & & \\
\hline Use of CPB & & & & & & & & \\
\hline None & & & & & Reference & & Reference & Reference \\
\hline Passive shunt & & & & & $2.0(0.9-4.5) ; .114$ & & - & - \\
\hline Left heart bypass & & & & & $0.8(0.3-2.4) ; .678$ & & $0.121(0.0-0.5) ; 004$ & $\begin{array}{l}0.103(0.0-0.5) \\
\quad .005\end{array}$ \\
\hline Full bypass/DHCA & & & & & $0.4(0.1-1.2) ; .107$ & & $0.424(0.1-1.5) ; .182$ & $\begin{array}{l}0.567(0.1-2.2) \\
.413\end{array}$ \\
\hline CPB time & $1.005(1.003-1.008) ;<.001$ & & $\begin{array}{l}1.006(1.004-1.009) ; \\
\quad<.001\end{array}$ & $\begin{array}{l}1.006(1.003-1.009) ; \\
<.001\end{array}$ & $\begin{array}{l}1.006(1.001-1.011) ; \\
\quad<.012\end{array}$ & & $\begin{array}{l}1.006(1.001-1.011) ; \\
\quad<.012\end{array}$ & \\
\hline AoX time & $1.006(1.002-1.011) ;<.001$ & & $\begin{array}{l}1.006(1.002-1.010) \text {; } \\
\quad .004\end{array}$ & & & & & \\
\hline Use of circulatory arrest & $0.5(0.2-1.1) ; .091$ & & $1.9(0.9-3.9) ; .083$ & $\begin{array}{l}3.4(1.1-10.4) ; \\
\quad .029\end{array}$ & & & & \\
\hline Glue use & $0.5(0.3-1.0) ; .039$ & & & & & & & \\
\hline $\begin{array}{l}\text { Postoperative } \\
\text { myocardial infarction }\end{array}$ & & & $7.3(2.2-24.4) ; .001$ & & & & & \\
\hline $\begin{array}{l}\text { Postoperative } \\
\text { CVA }\end{array}$ & $3.1(1.4-6.9) ; .006$ & & $8.2(3.0-22.9) ;<.001$ & & & & & \\
\hline $\begin{array}{l}\text { Postoperative } \\
\text { dialysis }\end{array}$ & $3.5(1.5-7.9) ; .003$ & & 8.1 (2.4-27.6); .001 & & $\begin{array}{l}6.4(1.8-22.3) \text {; } \\
\quad .004\end{array}$ & $8.4(1.7-41.6) ; .009$ & $5.9(1.8-18.9) ; .003$ & $\begin{array}{l}8.8(2.2-35.2) ; \\
.002\end{array}$ \\
\hline
\end{tabular}

OR, Odds ratio; $C I$, confidence interval; $C V A$, cerebrovascular accident; $C P B$, cardiopulmonary bypass; $D H C A$, deep hypothermia with circulatory arrest; $A o X$, aortic crossclamp time. 
APPENDIX 3. Univariable and multivariable analysis of factors for late mortality

\begin{tabular}{|c|c|c|c|c|c|c|c|c|}
\hline \multirow[b]{2}{*}{ Factor } & \multicolumn{2}{|c|}{ Group 1} & \multicolumn{2}{|c|}{ Group 2} & \multicolumn{2}{|c|}{ Group 3} & \multicolumn{2}{|c|}{ Group 4} \\
\hline & $\begin{array}{c}\text { Univariable HR } \\
(95 \% \text { CI }) ; P \text { value }\end{array}$ & $\begin{array}{l}\text { Multivariable HR } \\
(\mathbf{9 5} \% \mathbf{C I}) ; \boldsymbol{P} \text { value } \\
\end{array}$ & $\begin{array}{c}\text { Univariable HR } \\
(95 \% \text { CI }) ; P \text { value }\end{array}$ & $\begin{array}{l}\text { Multivariable HR } \\
(95 \% \mathrm{CI}) ; \boldsymbol{P} \text { value }\end{array}$ & $\begin{array}{c}\text { Univariable HR } \\
(95 \% \mathrm{CI}) ; \boldsymbol{P} \text { value }\end{array}$ & $\begin{array}{l}\text { Multivariable HR } \\
(95 \% \mathrm{CI}) ; \boldsymbol{P} \text { value }\end{array}$ & $\begin{array}{c}\text { Univariable HR } \\
(95 \% \text { CI); } P \text { value }\end{array}$ & $\begin{array}{l}\text { Multivariable HR } \\
(95 \% \text { CI }) ; P \text { value } \\
\end{array}$ \\
\hline Year of operation & $\begin{array}{l}0.977 \text { (0.947-1.008); } \\
\quad .142\end{array}$ & $\begin{array}{l}0.960(0.922-0.998) ; \\
\quad .041\end{array}$ & $\begin{array}{l}0.957(0.935-0.980) \\
\quad<.001\end{array}$ & $\begin{array}{l}0.937(0.913-0.962) \\
\quad<.001\end{array}$ & & & & \\
\hline Age & $\begin{array}{l}1.039(1.019-1.060) ; \\
\quad<.001\end{array}$ & $\begin{array}{l}1.046(1.023-1.069) ; \\
\quad<.001\end{array}$ & $\begin{array}{l}1.051(1.036-1066) \\
\quad<.001\end{array}$ & $\begin{array}{l}1.048(1.032-1.065) \\
\quad<.001\end{array}$ & $\begin{array}{l}1.060(1.041-1.080) \\
\quad<.001\end{array}$ & $\begin{array}{l}1.060(1.041-1.080) \\
\quad<.001\end{array}$ & $\begin{array}{l}1.097(1.041-1.155) \text {; } \\
.001\end{array}$ & $\begin{array}{l}1.097 \text { (1.041-1.155); } \\
.001\end{array}$ \\
\hline Gender (female vs male) & & & $1.6(1.1-2.2) ; .019$ & & & & & \\
\hline TAR vs other & & & & & $0.2(0.1-0.5) ;<.001$ & & & \\
\hline $\begin{array}{l}\text { Dissection } \\
\quad \text { type (1 vs 2) }\end{array}$ & $1.5(0.9-2.3) ; .094$ & & & & & & & \\
\hline Acute CVA & $2.7(1.1-6.8) ; .031$ & & & & & & & \\
\hline $\begin{array}{l}\text { Prior myocardial } \\
\text { infarction }\end{array}$ & $2.1(1.1-4.0) ; .024$ & & $2.5(1.5-4.3) ; .001$ & & & & & \\
\hline Hypertension & $1.6(1.0-2.5) ; .030$ & & $1.8(1.2-2.5) ; .002$ & & $2.2(1.4-3.4) ; .001$ & & & \\
\hline Diabetes mellitus & & & $4.3(2.1-8.9) ;<.001$ & & & & & \\
\hline COPD & $3.6(1.7-7.7) ; .001$ & $4.2(1.9-9.3) ;<.001$ & $3.1(1.9-5.2) ;<.001$ & & 2.6 (1.4-4.7); .002 & $1.9(1.0-3.5) ; .041$ & & \\
\hline Preoperative creatinine & $\begin{array}{l}1.003(1.002-1.005) ; \\
\quad<.001\end{array}$ & $\begin{array}{l}1.003(1.002-1.005) ; \\
\quad<.001\end{array}$ & $\begin{array}{l}1.008 \text { (1.003-1.012); } \\
\quad .001\end{array}$ & $\begin{array}{l}1.005(1.000-1.010) \text {; } \\
\quad .031\end{array}$ & & & & \\
\hline Reduced LVF & $3.9(1.4-10.8) ; .011$ & $6.2(1.9-20.2) ; .002$ & & & & & & \\
\hline Preoperative severe AI & $0.6(0.3-1.0) ; .045$ & & & & & & & \\
\hline Euroscore & $\begin{array}{l}1.016 \text { (1.000-1.032); } \\
\quad .046\end{array}$ & & $\begin{array}{l}1.043(1.025-1.060) ; \\
\quad<.001\end{array}$ & $\begin{array}{l}1.024 \text { (1.004-1.045); } \\
.021\end{array}$ & $\begin{array}{l}1.055(1.028-1.083) ; \\
\quad<.001\end{array}$ & & & \\
\hline $\begin{array}{l}\text { Coronary artery } \\
\text { disease }\end{array}$ & & & $2.2(1.4-3.3) ; .001$ & & & & & \\
\hline Urgency 1 vs $2-3$ & & & 2.2 (1.1-4.3); .026 & & $2.2(1.3-3.7) ; .003$ & & & \\
\hline $\begin{array}{l}\text { Use of circulatory } \\
\text { arrest }\end{array}$ & & & $1.7(1.2-2.5) ; .005$ & & & & & \\
\hline Aortic arch replacement & & & & & & & & \\
\hline None & & & Reference & & & & & \\
\hline Hemiarch & & & $1.5(1.0-2.2) ; .059$ & & & & & \\
\hline Full arch & & $\begin{array}{l}2.9(1.2-6.9) \text {; } \\
.015\end{array}$ & $3.0(1.8-5.2) ;<.001$ & $1.9(1.1-3.5) ; .026$ & & & & \\
\hline $\begin{array}{l}\text { Postoperative myocardial } \\
\text { infarction }\end{array}$ & & & $7.9(3.5-18.2) ;<.001$ & $\begin{array}{l}5.6(2.3-13.2) \\
\quad<.001\end{array}$ & & & & \\
\hline Postoperative CVA & & & & & $2.3(1.1-5.2) ; .003$ & & & \\
\hline $\begin{array}{l}\text { Postoperative renal } \\
\text { dysfunction }\end{array}$ & $2.5(1.4-3.9) ; .001$ & & 2.2 (1.3-3.7); .003 & & $2.1(1.3-3.3) ; .002$ & & & \\
\hline
\end{tabular}

$H R$, Hazard ratio; $C I$, confidence interval; $T A R$, traumatic aortic rupture; $C V A$, cerebrovascular accident; $C O P D$, chronic obstructive pulmonary disease; $L V F$, left ventricular function; $A I$, aortic insufficiency. 


\begin{tabular}{|c|c|c|c|}
\hline & Reoperations (\%) & Type of reoperation & $\mathbf{n}$ \\
\hline Group $1(n=261)$ & 48 & & \\
\hline \multirow[t]{3}{*}{ Aortic valve } & $19(7.3)$ & Replacement & 8 \\
\hline & & Valved conduit & 10 \\
\hline & & Allograft & 1 \\
\hline \multirow[t]{2}{*}{ Ascending aorta/arch } & $11(4.2)$ & Valved conduit & 2 \\
\hline & & Ascending/arch replacement & 9 \\
\hline \multirow[t]{2}{*}{ Descending/THAA/Abdominal } & $18(6.9)$ & Aortic replacement & 17 \\
\hline & & TEVAR & 1 \\
\hline Group $2(n=626)$ & 43 & & \\
\hline Aortic valve & $9(1.4)$ & AVR & 9 \\
\hline \multirow[t]{3}{*}{ Ascending aorta/arch } & $9(1.4)$ & Closure false aneurysm & 5 \\
\hline & & Root replacement (mechanical/allograft) \pm arch replacement & 2 \\
\hline & & Arch replacement & 2 \\
\hline \multirow[t]{2}{*}{ Descending/THAA/abdominal } & $25(4.0)$ & Aortic replacement & 23 \\
\hline & & TEVAR & 2 \\
\hline Group $3(n=175)$ & 18 & & \\
\hline \multirow[t]{3}{*}{ Ascending aorta/arch } & $7(4.0)$ & Acute type 1 dissection & 1 \\
\hline & & Valved conduit & 1 \\
\hline & & Ascending/arch replacement & 5 \\
\hline \multirow[t]{2}{*}{ THAA/abdominal } & $10(5.7)$ & Abdominal aortic replacement & 8 \\
\hline & & THAA & 2 \\
\hline Other & $1(0.6)$ & CABG & 1 \\
\hline Group $4(\mathrm{n}=97)$ & 2 & & \\
\hline Ascending aorta/arch & $1(1.0)$ & Ascending/arch replacement & 1 \\
\hline Descending & $1(1.0)$ & TEVAR & 1 \\
\hline
\end{tabular}

